\title{
A novel and feasible technique for diagnosis and treatment of small subepithelial tumors
}

Subepithelial tumors are commonly encountered during routine endoscopy, but their exact prevalence is uncertain. Their management and treatment stand in striking contrast to those of mucosal lesions: techniques are still early in evolution, numbers are small, and robust outcome data are sparse [1]. Using endoscopic ultrasonography (EUS), it has become possible to diagnose subepithelial lesions by evaluating the originating layer, echo level, and internal echo pattern of the lesion [2,3]. Lipomas, lymphangiomas, and fibromas originate from the third layer and leiomyomas and schwannomas from the fourth layer [4].

For diagnosis, forceps biopsy and EUSguided fine-needle aspiration (EUS-FNA) or unroofing using the ligate-unroofbiopsy technique can be performed. Endoscopic treatment is possible. In 2014, Binmoeller et al. [5], described the "suck - ligate-unroof-biopsy" technique using a detachable loop. We describe a novel and feasible technique to treat a gastric leiomyoma using a tissue helix, which was used to pull the lesion into the detachable loop ( $\triangleright$ Video 1 ).

A 39-year-old woman presented with dysphagia. Her symptoms had started 2 years earlier. Esophagogastroduodenoscopy (EGD) was performed and a subepithelial lesion was diagnosed. After that, EUS showed an anechoic image from the fourth layer, near the esophagogastric junction ( Fig. 1).

For the procedure, we used a doublechannel gastroscope, tissue helix, and a detachable nylon loop. First, we passed the tissue helix through the detachable loop. We pulled the lesion into the loop, which was then tightened at the base of the lesion, the suction was released, and the loop was deployed from the delivery sheath. We did this three times to ensure that no bleeding would occur.
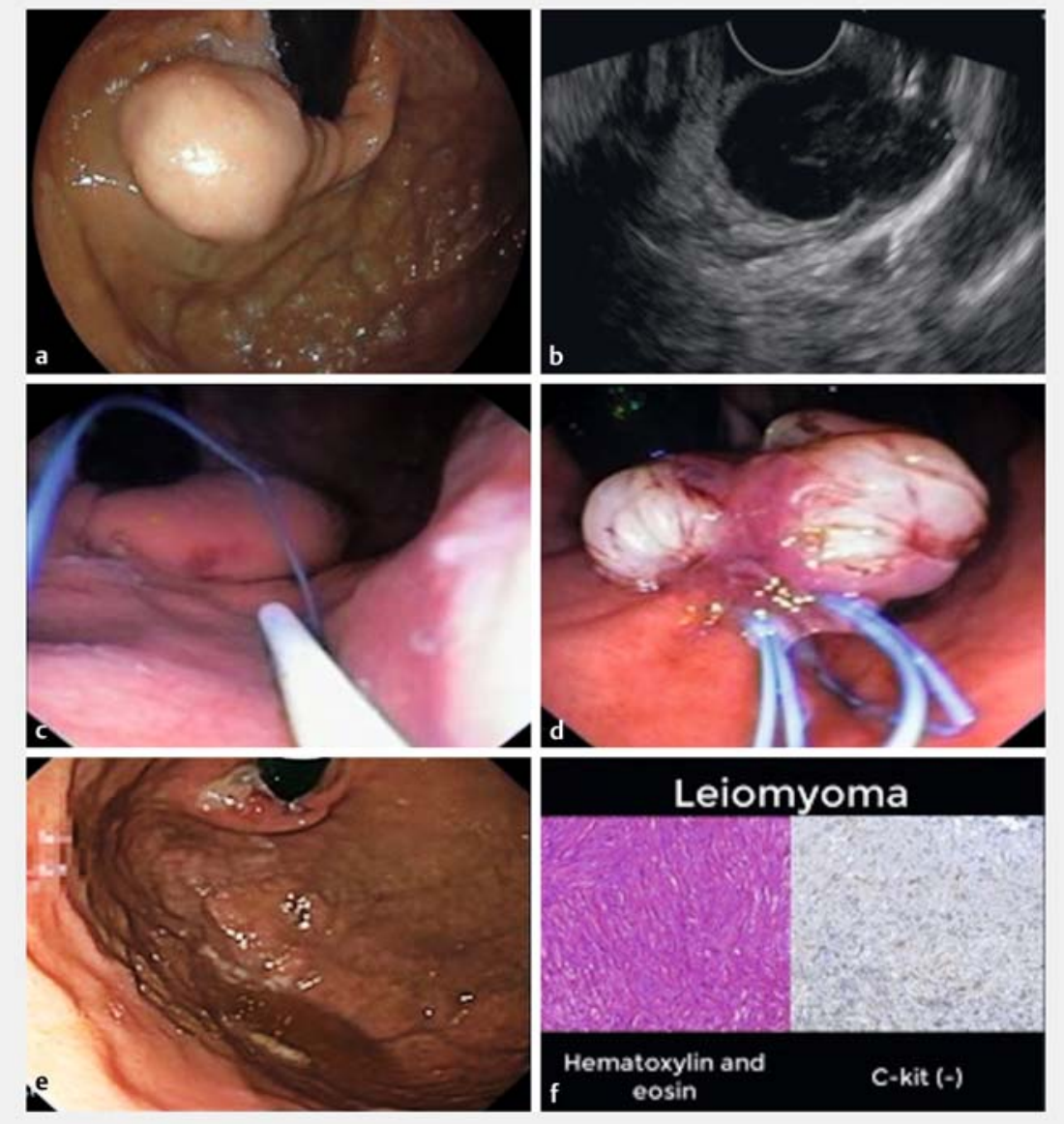

- Fig. 1 Subepithelial lesion before, during, and after the procedure. a Endoscopic assessment; $\mathbf{b}$ endoscopic ultrasonography; c loop ligating device and tissue helix; $\mathbf{d}$ final appearance after the procedure; e follow-up esophagogastroduodenoscopy (15 days after the procedure); f diagnosis: leiomyoma.

The tumor was "unroofed" with a needleEndoscopy_UCTN_Code_TTT_1AO_2AN knife. Two perpendicular incisions were made along the mucosal surface. Multiple biopsy specimens were obtained using a biopsy forceps. A leiomyoma was diagnosed.

A follow-up EDG was performed 15 days after the procedure. The patient was asymptomatic and only a scar was observed. 


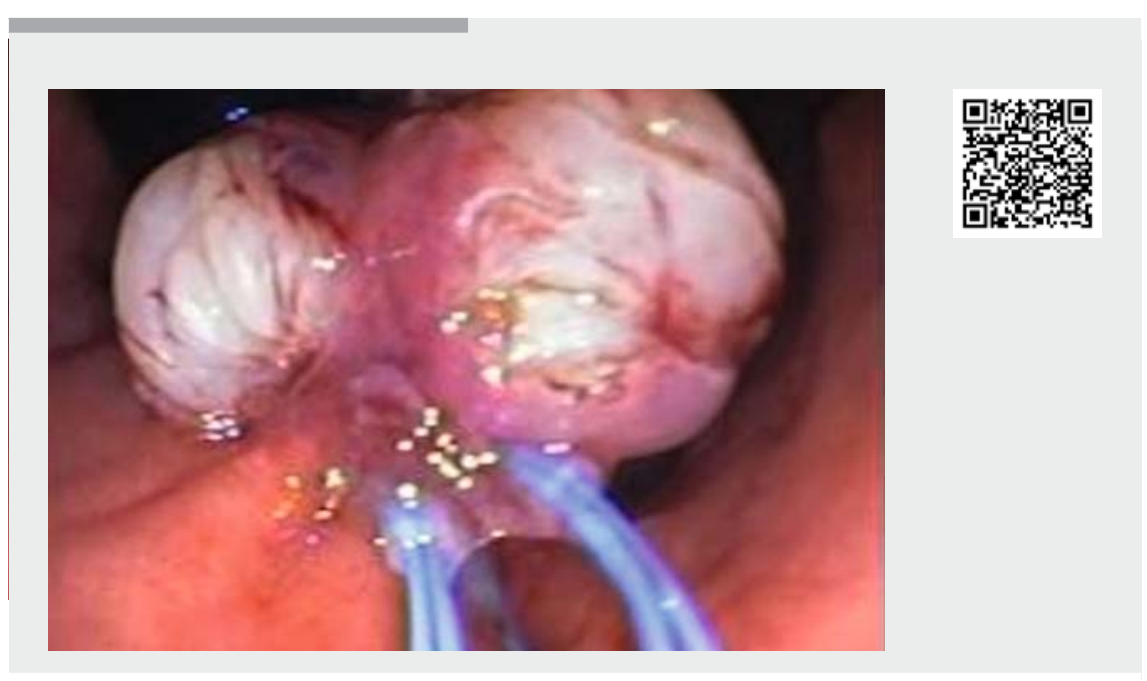

$\checkmark$ Video 1 Technique for diagnosis and treatment of subepithelial lesions. Tissue Helix was used to pulling the lesion into the datachable loop. After that, we unroofed the tumor with low risk of bleeding and diagnosed a leiomyoma using a biopsy forceps. Fifteen days after the procedure, the patient is asymptomatic.

The authors

Epifânio Silvino do Monte Junior, Dalton Marques Chaves, Christiano Makoto Sakai, Gustavo de Oliveira Luz, Igor Braga Ribeiro, Vitor Massaro Takamatsu Sagae, Eduardo Guimarães Hourneaux de Moura

Gastrointestinal Endoscopy Unit, Hospital das Clínicas da Faculdade de Medicina da Universidade de São Paulo, São Paulo, Brazil

\section{Corresponding author}

\section{Igor Braga Ribeiro, MD}

Av. Dr Enéas de Carvalho Aguiar, 225, 6º andar, bloco 3, Cerqueira Cesar, São Paulo, SP - 05403-010, Brazil igorbraga1@gmail.com Fax: +55-1-12661-6467
Bibliography

Endoscopy 2021; 53: E38-E39

DOI 10.1055/a-1178-0029

ISSN $0013-726 \mathrm{X}$

published online 29.5.2020

(C) 2020. Thieme. All rights reserved.

Georg Thieme Verlag KG, Rüdigerstraße 14 , 70469 Stuttgart, Germany

\section{ENDOSCOPY E-VIDEOS}

https://eref.thieme.de/e-videos

回回 Endoscopy E-Videos is a free 留 自: on interesting cases and new techniques in gastroenterological endoscopy. All papers include a high quality video and all contributions are freely accessible online.

This section has its own submission website at

https://mc.manuscriptcentral.com/e-videos
[1] Johns E, Binmoeller KF. Subepithelial lesions: a deeper look. Gastrointest Endosc 2016; 84: 930-932

[2] de Moura DTH, McCarty TR, Jirapinyo P et al. EUS-guided fine-needle biopsy versus fineneedle aspiration in the diagnosis of subepithelial lesions: a large multicenter study. Gastrointest Endosc 2020. doi:10.1016/j. gie.2020.02.021

[3] de Moura DTH, McCarty TR, Jirapinyo P et al. Endoscopic ultrasound fine-needle aspiration versus fine-needle biopsy for lymph node diagnosis: a large multicenter comparative analysis. Clin Endosc 2019. doi:10.5946/ce.2019.170

[4] Kida M, Kawaguchi Y, Miyata E et al. Endoscopic ultrasonography diagnosis of subepithelial lesions. Dig Endosc 2017; 29: 431443

[5] Binmoeller KF, Shah JN, Bhat YM et al. Suckligate-unroof-biopsy by using a detachable 20-mm loop for the diagnosis and therapy of small subepithelial tumors (with video). Gastrointest Endosc 2014; 79: 750-755 